\title{
SENSORY EVALUATION OF TAKE A BITE COOKIES
}

\author{
Dr. M. Padmaja \\ Assistant Professor, Department of Home Science, Ch. S. D. St. Theresa's College for Women (Autonomous),Eluru.
}

\begin{abstract}
A fiber and protein rich cookies were developed to promote low calorie high fiber and protein in diet. These cookies were designed to increase the utilisation of coconut, sesame meals in our diet. These Take A Bite Cookies help to increase the fibre and protein content in meal. These cookies are a healthy snack with low calories and can be suggested for therapeutic conditions like diabetes and constipation. Compared to regular cookies our product contains coconut meal, rice bran, sesame meal, jowar flour, bajra flour and jaggery as their nutritional value is commendable. Even though the usage of these ingredients is in small quantity, the health benefits obtained are innumerable. The samples of cookies prepared were subjected to sensory evaluation of colour, texture, shape, taste and odour by 100 untrained panellists by using Rating method. Rating was noted on the sensory scorecards. From the results obtained it was observed that $12 \%$ of them rated colour as excellent and $88 \%$ good. Regarding the texture $4 \%$ rating was excellent, $46 \%$ good, 33\% bad and $17 \%$ as very bad. Taste was rated with $17 \%$ excellent, $75 \%$ good and $8 \%$ bad. Odour rating was $17 \%$ excellent and $83 \%$ good. From the ratings obtained it was observed that majority of the sensory evaluators felt that the cookies were good and they can be suggested for consumption by all age groups.
\end{abstract}

Keywords: Cookies, meal, colour, texture, odour, taste.

\section{INTRODUCTION}

Cookies are commonly referred to as chewable biscuits and are widely consumed as they are rich in carbohydrates, fats and calories. Cookies referred to as baked snack that is small, flat and sweet which contain three major ingredients flour, sugar and fat. These ingredients are mixed with other minor ingredients like nuts, oats, egg. chocolate chips etc. to form dough. Due to appreciated rheological characteristics, wheat is principally used in bakery products. We developed a new variety of cookie- Take A Bite, using rarely consumed ingredients. Our aim for the development of this product is to create an interest among the people about the ingredients such as coconut meal, rice bran, sesame meal, jowar, bajra, and their nutritional value. Even though the usage of these ingredients is in small quantity, the health benefits obtained are innumerable.

Take A Bite- Fibre cookies are different from the cookies available in market now a days. The ingredients used for the preparation of cookies are quite different and which have nutritional importance and functional properties. A part from whole wheat flour ingredients used are bajra flour and jowar flour, which have high protein content, and these millets have nutraceutical properties. To these flours, minor ingredients rice bran, sesame meal and coconut meal, which contain high amounts of fiber and protein. Usually these meals are not included in daily diet as people believe that excess consumption may increase body weight, digestive problems may occur and allergies are seen in those who are sensitive to brans.

Considering all these points Take A Bite-Fiber Cookies were developed as they contain reasonable amounts of fiber which provide health benefits such as reducing constipation and the ingredients used contain complex carbohydrates, so that release of sugars into blood takes time. Most of the baked items like cookies contain huge amounts of sugar in order to main the better taste and texture, but Take A Bite-Fiber cookies are made with jaggery, which is beneficial to health. Since these cookies are not made with sugar they can be consumed by Diabetic and Cardiovascular Vascular Disease persons in limited amounts.

100 grams of cookies provide $481 \mathrm{k} . c a l$ of Energy, 59.17 grams of carbohydrates, 23.38 grams of fat, 6.7 grams of proteins and 4.6 grams of fiber. These cookies can be consumed as snacks or with combination of tea or milk in order to fill the stomach with nutrients. Take a bite- fiber cookies are suggested to any age people from school going children to old age people without any fear. Especially these are recommended to the cardiac, diabetic and constipation patients and also for obese persons for weight loss. These cookies help to increase the fiber quantity in body and keep them away from digestion problems and keep healthy. 


\section{METHODOLOGY:}

\subsection{Development of recipe for the preparation of fibre and protein cookies:}

The recipe for fibre and protein enriched cookies was developed using different ingredients such as Rice bran, sesame meal, coconut meal, wheat flour, bajra flour, jowar flour, jaggery and butter. Butter was whisked with jaggery until it gets a creamy texture. In a bowl take all the dry ingredients and mix $15 \mathrm{gms}$ of coconut meal, $15 \mathrm{gms}$ of sesame cake powder, 30 gms of multi grain powder (ragi flour, soybean flour, jowar flour, bajra flour) and sieve it properly. Now the butter mix is added and made into a homogenous mass. Now take the dough and make round balls and place on the baking pan after greasing with butter. Bake at $160^{\circ} \mathrm{C}$ for 15 minutes. Take out of the oven and cool at room temperature.

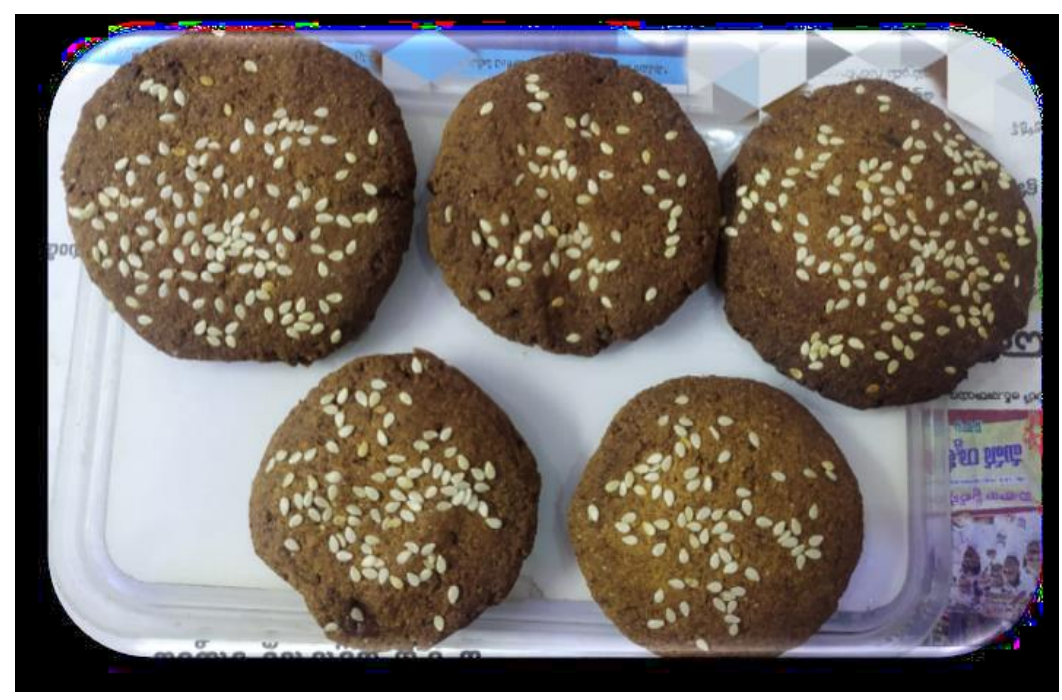

Fig.1 Take A Bite Cookies

\subsection{Sensory Evaluation:}

\section{RESULTS AND DISCUSSION:}

The samples of cookies prepared were subjected to sensory evaluation of colour, texture, shape, taste and odour by 100 untrained panellists by using Rating method. Rating was noted on the sensory scorecards. In order to evaluate the acceptance of product the respondents were asked to rate the product under 4 different categories namely excellent, good, bad and very bad respectively. Based on the sensory scores the cookies sample was optimized and the best product was considered for customer acceptance.

From the results obtained it was observed that $12 \%$ of them rated colour as excellent and $88 \%$ good. Regarding the texture $24 \%$ rating was excellent, $66 \%$ good and $10 \%$ bad. Taste was rated with $17 \%$ excellent, $75 \%$ good and $8 \%$ bad. Odour rating was $17 \%$ excellent and $83 \%$ good.

\begin{tabular}{|l|l|l|l|l|}
\hline Category & Excellent & Good & Bad & Very bad \\
\hline Colour & $12 \%$ & $88 \%$ & $0 \%$ & $0 \%$ \\
\hline Texture & $24 \%$ & $66 \%$ & $10 \%$ & $0 \%$ \\
\hline Taste & $17 \%$ & $75 \%$ & $8 \%$ & $0 \%$ \\
\hline Odour & $17 \%$ & $83 \%$ & $0 \%$ & $0 \%$ \\
\hline
\end{tabular}

Table 1: Sensory Evaluation of Take A Bite Cookies 
International Advanced Research Journal in Science, Engineering and Technology

Impact Factor $7.105 \div$ Vol. 9, Issue 1, January 2022

DOI: $10.17148 /$ IARJSET.2022.9149

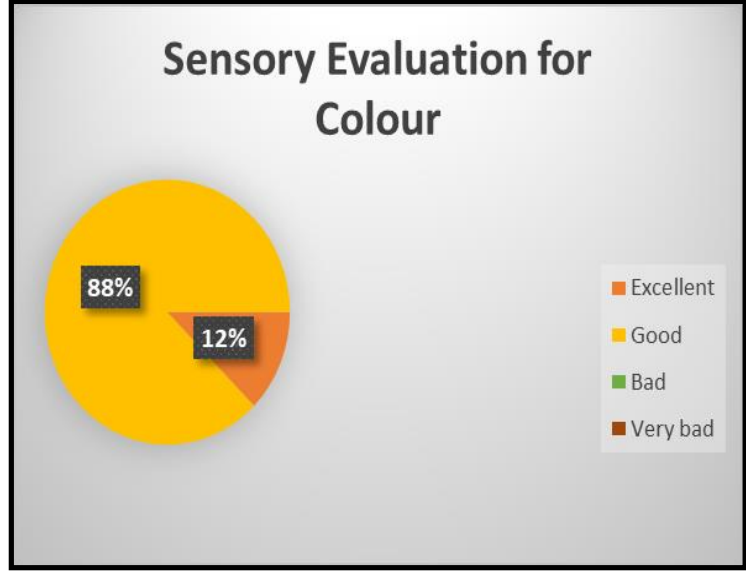

Fig.2: Sensory Evaluation of Take A Bite Cookies for Colour

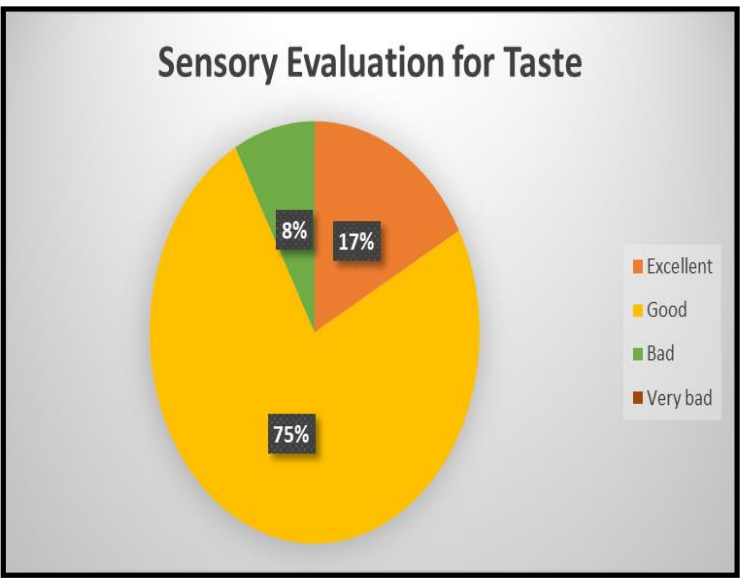

Fig.4: Sensory Evaluation of Take A Bite Cookies for Taste

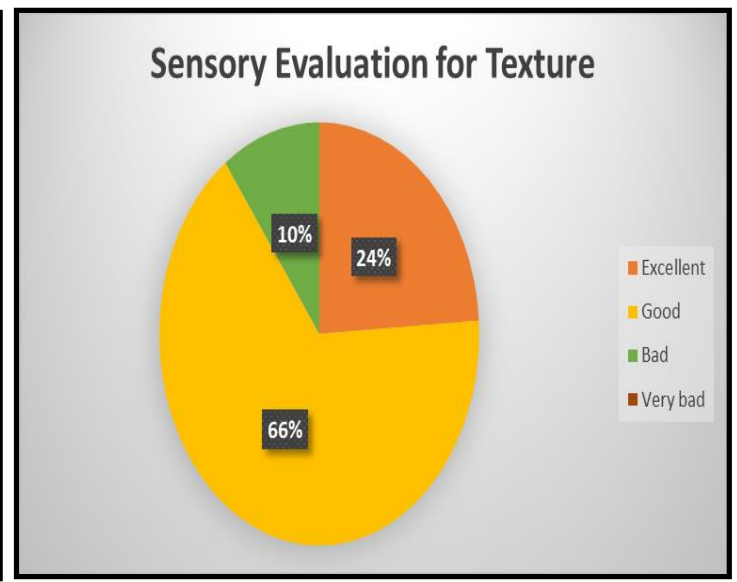

Fig.3: Sensory Evaluation of Take A Bite Cookies for Texture

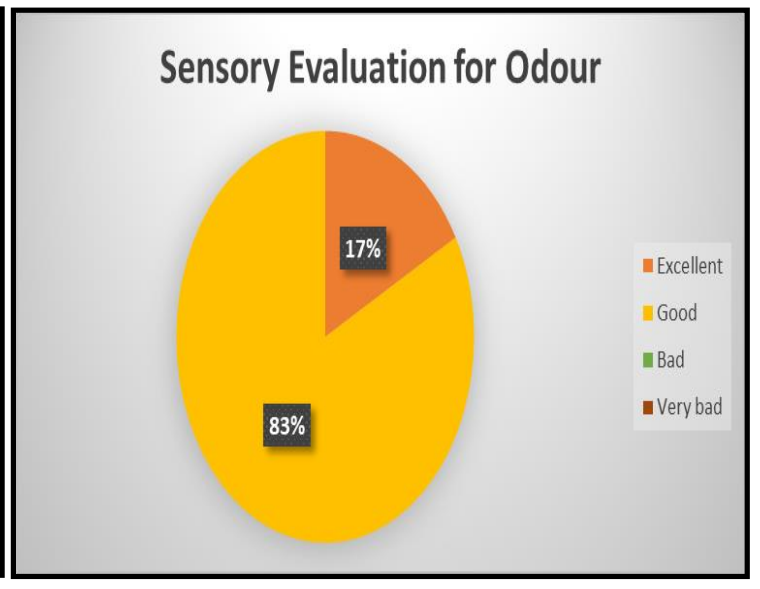

Fig.5: Sensory Evaluation of Take A Bite Cookies for Odour

Overall rating of the cookies was as follows- Colour was rated as Good by $88 \%$ of thr respondents, texture was rated as Good by $66 \%$, Taste was rated as Good by $75 \%$ and Odour was rated as Good by $83 \%$ of them. Only $8 \%$ of them felt the taste was bad and none of them rated the cookies as very bad in terms of colour, texture, taste and odour. From the ratings obtained it was observed that majority of the sensory evaluators felt that the cookies were good and they can be suggested for consumption by all age groups.

\section{CONCLUSION}

Cookies are good carrier of nutrients like carbohydrate and fat enriched with fiber and protein. Usually refined wheat flour is used but in this product maida is partially replacing refined wheat flour with fiber and protein rich flours to an acceptable level. Sesame meal, coconut meal, sorghum flour and bajra were recognized as potential source of protein whereas rice bran and whole wheat flour were potentially fiber rich. From the product we developed it was concluded that availability of good amounts of protein and fiber can be obtained. Rice bran supplementations significantly improve the dietary fiber, mineral and protein content of the cookies. Coconut meal, which is rich in fiber and MCTs, promote stable blood sugar and heart health plus its delicious and versatile making it smart choice. Sesame seeds are a good source of healthy fats, protein, B-vitamins, minerals, fiber, antioxidants and other beneficial plant compounds. Jowar is an ancient grain, which is rich in fiber being gluten free it is a healthy diet for diet. Bajra helps in reducing LDL and bad cholesterol and it may help prevent chronic conditions like diabetes and heart disease. Whole-wheat flour is widely considered healthier. It is a good source of protein, fiber and a variety of vitamins and minerals. Compared to refined sugar jaggery appears nutritious. Refined white sugar contains only empty calories that is, calories without any vitamins and minerals, when it comes to jaggery it is described as more nutritious. Butter helps to lower chances of cancer and as 


\section{International Advanced Research Journal in Science, Engineering and Technology \\ Impact Factor $7.105 \div$ Vol. 9, Issue 1, January 2022 \\ DOI: 10.17148/IARJSET.2022.9149}

it is high in beta-carotene a compound that our body converts into vitamin-A. As all these ingredients are main core aspects in our product, it is more recommendable and healthier option that can be taken by people of all age group.

\section{REFERENCE:}

1. Dietetics seventh edition -B. Srilakshmi, 2014,pg: 232, 257, 276, 296, 298, 320, 332.

2. Nutritive Value of Indian Foods-C. Gopalan, B.V. Rama Sastri and S. C. Balasubramanian, 1989, pg:5

3. The High - Fibre Diet Book -Dietary fibre and your health: The essential handbook-Andrew Stanway MB MRC, 1976,pg: 106.

4. Walsh Bryan. The Truth About Fat. Time Magazine. 2014.

5. Bittman M. Butter is Back. The New York Times. 2014. March 25, 2014: Sect. The Opinion Pages.

6. Mozaffarian D, Ludwig DS. Dietary guidelines in the 21 st century - a time for food.

7. JAMA. 2010;304(6):681-2. 10.1001/jama.2010.1116 [PubMed] [CrossRef]

8. Dietary Guidelines Advisory Committee. Scientific; Report of the 2015 Dietary Guidelines Advisory Committee (Advisory Report). In: U.S. Department of Health and Human Services (HHS) and the U.S. 3 Department of Agriculture (USDA), editor. 2015.

9. Karandeep Kaur, Navnidhi Chhikara, Poorva Sharma, MK Garg, Anil Panghal Foods \& Raw Materials 7 (2), 2019.

10. Eckel RH, Jakicic JM, Ard JD, Miller NH, Hubbard VS, Nonas CA, de Jesus JM, Sacks FM, Lee IM, Smith SC, Jr, Lichtenstein AH, Svetkey LP, Loria CM, Wadden TW, Millen BE, Yanovski SZ. AHA/ACC Guideline on Lifestyle Management to Reduce Cardiovascular Risk: A Report of the American College of Cardiology/American Heart Association Task Force on Practice Guidelines. Journal of the American College of Cardiology. 2013;2013 [PubMed]

11. Belobrajdic, D.P. \& McIntosh, G.H. (2000) Dietary butyrate inhibits NMU-induced mammary cancer in rats. Nutritionand Cancer 36, 217-223.Belury, M.A. (2002) Dietary conjugated linoleic acid in health: physiological effects and mechanisms of action in Asian Journal of Dairy \& Food Research . Mar2017, Vol. 36 Issue 1, pp. no. 63-Tanwar, Beenu; Dhillon, Meenakshi

12. Hu FB, Stampfer MJ, Manson JE, Ascherio A, Colditz GA, Speizer FE, Hennekens CH, Willett WC. Dietary saturated fats and their food sources in relation to the risk of coronary heart disease in women. The American journal of clinical nutrition. 1999;70:1001-1008. [PubMed]

13.Lopez-Garcia E, Schulze MB, Meigs JB, Manson JE, Rifai N, Stampfer MJ, Willett WC, HHu FB, Stampfer MJ, Manson JE, Ascherio A, Colditz GA, Speizer FE, Hennekens CH, Willett WC. Dietary saturated fats and their food sources in relation to the risk of coronary heart disease in women. The American journal of clinical nutrition. 1999;70:1001-1008. [PubMed]

13. Roach C, Feller SE, Ward JA, Shaikh SR, Zerouga M, Stillwell W. Comparison of cisand trans fatty acid containing phosphatidylcholines on membrane properties. Biochemistry. 2004;43:6344-51. [PubMed]

14. Siri-Tarino PW, Sun Q, Hu FB, Krauss RM. Meta-analysis of prospective cohort studies evaluating the association of saturated fat with cardiovascular disease. The American journal of clinical nutrition. 2010;91:535-546. [PMC free article] [PubMed]

15. Karandeep Kaur, Navnidhi Chhikara, Poorva Sharma, MK Garg, Anil Panghal Foods \& Raw Materials, 7 (2), 2019. 